\title{
REPERTÓRIOS MORAIS E ESTRATÉGIAS INDIVIDUAIS DE BENEFICIÁRIOS E CADASTRADORES DO BOLSA FAMÍLIA
}

Neste artigo fazemos uso da antropologia e da sociologia para analisar o impacto da cultura e do social na regulação das representações, classificações e práticas entre agentes do Estado e os "pobres". Em particular, ao tratar do tema da pobreza (ou das políticas para combatê-la) emerge uma infinidade de estudos que enseja múltiplas formas de leitura, análises, interpretações, recortes e vieses teóricos diferentes. Por esta razão, gostaríamos de esclarecer que a conceituação de pobreza com a qual trabalhamos afasta-se tanto do campo epistemológico da Economia, exatamente porque este limita a pobreza, em grande medida, aos aspectos de renda e ao acesso ao consumo, quanto das abordagens utilizadas pela Ciência Política, que tende a priorizar as análises sobre a eficácia das políticas. Conforme salienta Peirano (2006: I22):

Para os cientistas políticos, o tema sugere, imediatamente, questões de justiça, participação política, direitos sociais. O antropólogo propõe-se, em relação à mesma questão, perguntas mais simples: O que é um cidadão? Qual a concepção que distintos grupos têm de cidadania? Por meio de que símbolos é possível detectar essas formulações?

Tanto para o sociólogo quanto para o antropólogo, seria interessante então analisar o Estado, a partir de sua construção social, como uma instituição que forma grupos e produz identidades. Nesse sentido, pretendemos discutir o processo lento, conflituoso e diverso da construção de políticas públicas, divergindo da visão que enxerga o Estado como uma instituição 
homogênea, universal e acabada. Strobel (2008: 65), por exemplo, afirma que a conceituação de pobreza não pode se restringir ao aspecto da renda, tendo em vista que o processo de pauperização apresenta múltiplas formas, nas quais, às vezes, intervêm aspectos simbólicos, políticos, sociais e econômicos. Afirma, ainda, que mesmo o discurso da exclusão pode ser interpretado como reducionista, na medida em que ele unifica as situações e acaba por impor uma imagem muito simples de sociedade dual dividida entre aqueles que estão in (dentro) e aqueles que estão out (fora) do acesso a bens, serviços e direitos sociais. O autor argumenta que a utilização do conceito de exclusão pode servir ora como um meio de silenciar os pobres ${ }^{\mathrm{I}}$ e naturalizar o fenômeno da precariedade, ora como um artifício retórico para acomodar a situação.

As análises sobre as políticas públicas de combate à pobreza no Brasil (em especial aquelas feitas pela Ciência Política) utilizam, de forma recorrente, a política em si (e seus objetivos), para pensar as consequências dessa ação pública, sem, no entanto, dar importância à construção social da produção dos discursos políticos e sem avaliar a defasagem entre as normas institucionais e as práticas cotidianas. Assim, ora tomam a política como um "ente" que possui uma racionalidade estratégica, direcionando seus interesses para a população-alvo, ora analisam os impactos da política sobre o grupo em questão, procurando medir a eficácia de tais ações. Porém, isto não quer dizer que os efeitos previstos se concretizam ou que outros ocorram necessariamente.

Nesse sentido, dentro desta ampla questão fizemos um recorte específico sobre os discursos, as representações e as práticas (sobretudo morais e simbólicas) dos atores do Estado em relação aos pobres beneficiários ou candidatos ao Programa Bolsa Família (PBF). Para tanto, realizamos um trabalho de campo sobre o cotidiano de um grupo de "beneficiários" desse programa em uma periferia do Estado do Rio de Janeiro. Sob este olhar, propomos discutir duas questões principais: o processo de estigmatização social (e humilhação moral) no setor de cadastramento do Programa Bolsa Família e as percepções dos beneficiários sobre os critérios da escolha estatal.

Há décadas, acumula-se uma vasta produção acadêmica voltada para a conceituação das desigualdades sociais e da pobreza como fenômenos sociais. Mapear essas referências seria uma tarefa inesgotável. Assim, esta discussão teórica apresenta apenas parte do debate, com o objetivo de construir um pano de fundo mais geral, sobre o qual desdobraremos nosso tema de pesquisa. Por um lado, trataremos a pobreza sob seu aspecto cultural e moral e, por outro, analisaremos as distinções sociais sob o plano das fronteiras simbólicas. Este tipo de enfoque não tem sido tão aprofundado no âmbito das Ciências Sociais, poucos são os estudos que abordam as representações coletivas e a dimensão simbólica em torno do funcionamento dos grupos sociais em relação ao Estado. 
$\mathrm{Na}$ verdade, é preciso insistir sobre as dimensões sociopolíticas, muitas vezes negligenciadas, face ao desenvolvimento da pobreza. De acordo com Strobel (2008: 7I) seria necessário, por um lado, analisar as formas de exclusão simbólica e de estigmatização de grupos sociais compreendidos como diferentes (ou desviantes). Por outro, seria interessante investigar os processos (institucionalizados ou não) de supressão de direitos que representam formas clôture de uma comunidade local, profissional e nacional.

A questão da pobreza ganhou mais visibilidade no âmbito estatal a partir da crise dos anos I980, quando se generalizou uma série de debates públicos sobre como enfrentá-la. Todavia, é nos anos I99o que se assume (tanto no Brasil quanto em outros países da América Latina e do mundo), mais sistematicamente, a necessidade do combate à pobreza, diante da constatação de que as reformas econômicas realizadas (ligadas ao mercado e à reestruturação produtiva) não seriam suficientes para gerar uma recuperação que levasse à redução significativa da pobreza. É nesse contexto que emergem, ainda na década de I990, as políticas de transferência de renda, a maior delas aparecendo em cena no Brasil nos anos 2000: o Programa Bolsa Família. Tal nomeação que centraliza o papel da família (e em particular o papel da mãe $e^{2}$ neste processo) no interior da política se assemelha às definições de outros programas de transferência de renda na América Latina, tais como: Programa de Asignación Familiar, em Honduras (I990), Mi Família, da Nicarágua (2000) e Famílias en Acción, da Colômbia (200I). Aqui no Brasil, o Programa Bolsa Família vai ganhando, gradativamente, apoio de um amplo leque de forças políticas de matizes ideológicos variados e da opinião pública, embora também enseje um conjunto amplo de controvérsias.

$\mathrm{Na}$ medida em que as políticas sociais de combate à pobreza e de desenvolvimento econômico vêm organizando e prescrevendo "merecedores" das políticas sociais (ver Steensland, 2006), por fazerem parte da categoria de pobres, acreditamos ser fundamental investigar como e através de que processos se organiza a compreensão do que é ser pobre e que repercussões isso tem entre as famílias beneficiárias de um programa de transferência de renda brasileiro.

\section{UMA BREVE HISTÓRIA DO PBF}

Como um eixo norteador do antigo Programa Fome Zero, 3 o Programa Bolsa Família, criado em 2003, insere-se no projeto político do Governo de Luiz Inácio Lula da Silva. Este programa tem origem na unificação de outros não contributivos já existentes no Governo Fernando Henrique Cardoso, a saber: o Bolsa Escola, o Cartão Alimentação, o Auxílio-Gás e o Bolsa Alimentação, todos criados no período $2001-2003 .^{4}$ 
Em pouco tempo, o PBF tornou-se o maior programa de combate à pobreza no Brasil e um dos maiores do mundo; até março de 20I3, atendia a mais de 13 milhões de famílias, segundo dados do Ministério de Desenvolvimento Social e Combate à Fome (MDS, 2013). ${ }^{5} \mathrm{Em}$ seu desenho, o PBF apresenta basicamente dois objetivos: o alívio imediato da pobreza, através da transferência direta de renda para famílias pobres, priorizando as mulheres como responsáveis pelo benefício, e o exercício de direitos sociais básicos relacionados à saúde e à educação, com a finalidade de romper com o ciclo intergeracional de reprodução da pobreza.

Os debates públicos e acadêmicos sobre o Programa Bolsa Família têm se concentrado, notadamente, em avaliar a eficácia do Programa: sua focalização na população considerada pobre, o cumprimento das condicionalidades relativas à frequência escolar das crianças e o acesso à saúde e à segurança alimentar. Ou seja, a maioria dos estudos até aqui produzidos se dedica, sobretudo, a analisar os impactos do PBF sobre a população beneficiada, isto é, objetiva medir o grau de aproximação ou de distanciamento dos resultados obtidos frente às metas estabelecidas pelo próprio Programa. Nosso interesse em pesquisar o Programa Bolsa Família é de outra ordem.

Gostaríamos de contribuir para a reflexão sobre as políticas públicas como um conjunto de concepções e ações que afetam a sociedade, ou parte dela, para além de seus objetivos declarados. Tais efeitos podem ser de natureza simbólica, inscrevendo-se no tecido relacional de uma comunidade, gerando novas formas de solidariedade e tensões entre grupos sociais.

Nosso olhar sobre a temática da pobreza envolve uma discussão em torno de três objetivos. Em primeiro lugar, buscamos compreender como os candidatos ao benefício interpretam e negociam, com os operadores do Programa, as categorias por eles imputadas. Em segundo, procuramos explorar em que medida o grupo de beneficiários passa a se perceber e ser percebido como um grupo social diferenciado no setor de cadastramento. Basicamente perseguiremos duas questões: I) em que consistiria essa diferenciação? e 2) que valores (ou múltiplas moralidades) são aplicados pelos beneficiários e candidatos, para justificar a participação (ou não) no Programa?

Neste nível de análise, gostaríamos de compreender em que medida esses profissionais tipificam a população de baixa renda e os "merecedores" do benefício, além de entender a lógica pela qual os agentes implementadores do Bolsa Família produzem tais tipificações, ou seja, quais seriam os instrumentos (burocrático, econômico, moral e/ou conhecimento dos candidatos) acionados para legitimar e certificar suas posturas. Apresentaremos, ainda, os critérios de justificação usados pelos beneficiários para explicar o fato de serem "merecedores" do benefício e a maneira pela qual percebem sua trajetória após receberem um recurso assistencial. Sofrem constrangimentos e/ou controles particularmente relacionados à sua posição de depen- 
dentes do Estado? Em síntese, buscamos apreender o movimento de constituição da "carreira moral" dos beneficiários, quando, concomitantemente, o "controle disciplinar" (Goffman, I987) passa a ser exercido sobre eles na esfera pública. A ideia, então, é pensar como se cria, a partir de uma identificação formal e informal, uma imagem pública dos beneficiários, através da qual estes precisam ser moralmente vigiados, controlados e, até mesmo, punidos, se necessário.

Para compreender melhor a complexidade da formação do status de beneficiário, percorremos diversas esferas (formais e informais) no contexto de pobreza de Itaboraí (periferia da região metropolitana do Rio de Janeiro) por onde esses indivíduos passam, tais como: escolas, postos de saúde, coordenação do Bolsa Família e o setor de cadastramento, Centro de Referência de Assistência Social (CRAS), restaurante popular e a própria vizinhança. Através da observação participante podemos dizer que as relações estabelecidas entre beneficiários e não beneficiários (atores institucionais e vizinhos) fundam-se em uma matriz moral, com a presença de fofocas, julgamentos morais e controles sociais específicos, que se desenvolvem em torno da figura do beneficiário. A partir deste estudo sobre as interações cotidianas dos pobres, vemos avançar um processo de diferenciação simbólica entre pessoas que dependem do serviço de Assistência Social e pessoas que não dependem de tal serviço. Vejamos agora como ocorre a construção de processos de estigmatização social, humilhação moral e a internalização da vergonha por ser beneficiário de um programa de combate à pobreza.

\section{ESTIGMATIZAÇÃO SOCIAL, HUMILHAÇÃO E VERGONHA Setor de cadastramento}

Gostaríamos de analisar como, ao se tornarem beneficiários de um programa de transferência de renda, as pessoas passam a vivenciar experiências de humilhação e de preconceito que marcarão suas trajetórias no âmbito institucional (relacionadas, de modo geral, ao Programa Bolsa Família) e na vida social do bairro. Aqui se torna importante mencionar que a função do cadastramento do PBF não é eleger beneficiários, mas somente incluir os candidatos à bolsa no sistema federal chamado CADÚNICO. ${ }^{6}$

Uma beneficiária de nome Adelir7 afirma que, no momento de realização do cadastro, viveu a experiência da humilhação. "Naquele dia ali, eu me senti humilhada. Tem muita gente que desiste por isso, né? Falei que estava passando necessidade... e eles já te tratam com desconfiança, acha que você tá mentindo". Para Luciana, a questão mais problemática é a dependência financeira com relação ao Estado. Este é o fator que mais a constrange como beneficiária: 


\begin{abstract}
Ahhh, é muito humilhante não ter trabalho e ficar só recebendo dos outros. Você se sente inútil. A pessoa quer trabalhar e ganhar pelo seu próprio esforço e não ir no banco para ganhar dinheiro do Governo. Parece que é até um favor, né? Lá na fila, ninguém fala nada de sentir vergonha, mas, na hora de receber, tem um monte de colega que esconde o cartão. Lá na fila, às vezes a gente escuta alguns comentários, tipo: "lá vem eles, ficam aí só encostados no dinheiro dos outros". É muito ruim.
\end{abstract}

Afirmando sofrer constrangimentos, outra beneficiária de nome Naiara salienta que a humilhação sofrida foi exercida, sobretudo, pelas atendentes do setor de cadastramento no âmbito da coordenação do Bolsa Família.

Elas dizem: "É só isso mesmo, querida". "O Governo não vai dar mais nada não!". "Vocês têm que trabalhar!". "Não tem mais nada não!". Aí eu nem vou mais lá na casa amarela ${ }^{8}$ porque não quero ser maltratada. Elas lá ficam falando para qualquer um ouvir: "Vocês ficam na farra e não querem nada, só ganhar dinheiro fácil!"

A maioria dos beneficiários se sente desconfortável ao interagir com os atendentes da coordenação do PBF. De fato, verificamos (durante nossa observação participante) a existência de um conjunto de problemas que envolvem a interação dos beneficiários com os profissionais que trabalham na gestão do PBF naquele espaço: preconceitos, julgamentos morais, situações de constrangimento e humilhação. Estas adversidades são relatadas tanto pelos beneficiários quanto pelo próprio corpo técnico vinculado ao Programa (sobretudo as Assistentes Sociais e as Agentes de Saúde) que tentam redirecionar as condutas dos atendentes da "porta de entrada" para que elas se desviem de práticas discriminatórias.

Tais controles sociais induzem a um processo classificatório moral, tornando pública a imagem negativa do beneficiário. A ideia de "má reputação" (Goffman, I988: 80) nos ajuda a compreender melhor o desenvolvimento de diversas categorias valorativas sobre a figura do beneficiário, tais como: "gastam dinheiro com cachaça", "deixam as crianças largadas", "eles são aproveitadores", "vagabundos" etc.

Ao mesmo tempo em que se desenvolve uma relação pautada no constrangimento e humilhação, há outras situações em que, sob a égide da lógica administrativa, a demanda do candidato (cadastramento) ou beneficiário (recadastramento) é feita rapidamente, sem envolvimento da atendente, cumprindo sua função burocrática de preenchimento dos dados. Vejamos o caso relatado por Maria:

Foi uma coisa assim, direta: ela começou a fazer várias perguntas, muitas mesmo, e foi preenchendo, marcando, e aí eu perguntei quando eu ia receber e ela falou: "Isso aí é lá com o Governo Federal. Eu não sei de nada". Depois que ela acabou, me deu um papel com o telefone e falou: "Pode ir, tá feito".

No mesmo contexto, pode se desenvolver ainda outro tipo de interação do atendente com o candidato (e/ou beneficiário), na qual os atendentes oferecem recursos e encaminhamentos à demanda. É o que aparece na fala de Jucélia: 
Quando eu fui, assim, até que a mulher preencheu meus dados direitinho, perguntou se eu queria, se estava faltando alguma coisa. Eles me ajudaram assim... a mulher falou dos cursos que tinha, que eu tinha que pesar meu filho que estava muito magro na época. Aí ela me deu o telefone do posto que pesa lá.

Nesse sentido, poderíamos analiticamente tipificar essas interações de três formas:

\begin{tabular}{l|l}
$\begin{array}{l}\text { Tipificação da Interação } \\
\text { Atendente } \longleftrightarrow \text { Candidatos e Beneficiários }\end{array}$ \\
\hline $\begin{array}{l}\text { Interação } \\
\text { Estigmatizante }\end{array}$ & $\begin{array}{l}\text { Ofensas e humilhações objetivam destruir a } \\
\text { fachada do beneficiário. }\end{array}$ \\
\hline $\begin{array}{l}\text { Interação } \\
\text { Burocrática }\end{array}$ & $\begin{array}{l}\text { Função administrativa de preenchimento do } \\
\text { cadastro ou do recadastramento. A rapidez e a } \\
\text { eficácia movem a ação dos atendentes. }\end{array}$ \\
\hline $\begin{array}{l}\text { Interação } \\
\text { Assistencial }\end{array}$ & $\begin{array}{l}\text { Acontece quando os atendentes fornecem } \\
\text { orientações, indicações e encaminhamentos. }\end{array}$ \\
\hline
\end{tabular}

Quando se trata da situação de (re)cadastramento, as interações de candidatos e/ou beneficiários com os atendentes podem se desenvolver basicamente de três formas: I) interação estigmatizante: nas quais as ofensas e as humilhações objetivam destruir a fachada do beneficiário; 2) interação assistencial: quando os atendentes fornecem recursos de auxílio como, por exemplo, encaminhamentos; e 3) interação burocrática: atendentes exercem função administrativa de preenchimento do cadastro ou do recadastramento.

Em outras palavras, no âmbito do atendimento, os profissionais realizam julgamentos normativos variados, acabando por atravessar a fronteia virtual entre "burocracia" e "cultura". Os próprios profissionais oscilam entre a lógica racional/legal (quando interagem de forma assistencial ou burocrática) e as avaliações valorativas (em que a moralidade e o estigma se apresentam de forma mais forte).

Pretendemos agora mostrar como os atores institucionais percebem a trajetória dos candidatos ao Programa Bolsa Família, desde a fase de cadastramento até o momento de se tornarem beneficiários do Programa, quando passam a cumprir as exigências da política. Como visualizam suas interações com o conjunto de beneficiários? O que destacam como mais importante no contexto da interação? Existiria um processo de degradação da imagem do beneficiário, chegando a ser desqualificado moral e socialmente? Estas questões nortearam esta parte de nossa análise. 
De imediato, Élida (Assistente Social) aponta efeitos não premeditados do Programa, destacando a emergência de preconceitos relacionados à figura do beneficiário. Vejamos sua fala:

Acho que o Bolsa é como se fosse uma humilhação, e a própria pessoa que vai receber vai incorporando esse pensamento de que é miserável, né? Acho que quando o Governo pensou nisso foi pra ajudar a suprir as necessidades, mas as pessoas acabam se sentindo humilhadas... Até porque o valor é muito pequeno. E pra receber precisa de tanta coisa...

Já Cacilda (Agente de Saúde) percebe uma diferença no grau de humilhação relacionado ao valor do benefício; assim, quanto mais baixo o valor, maior seria a possibilidade de os beneficiários sentirem vergonha ou passarem por situações humilhantes. Cacilda também percebe que os beneficiários sentem vergonha, sobretudo quando o nome deles consta na ficha de atendimento do Serviço Social.

É, eles têm vergonha, mas disfarçam, tentam não demonstrar... Quando a gente pergunta sobre isso, aí eles desconversam. No dia a dia, que eles têm mais vergonha do que o medo da denúncia, porque quando bate o nome lá, eles pensam: "Já vão me tratar como um pobre coitado." [...] Eu acho que as pessoas mais humildes têm ainda mais vergonha de estar recebendo o Bolsa. Tem um caso de uma senhora que recebe 30 e poucos reais, que foi pra resolver um problema do cartão, e não consegue ficar em lugar fechado. Foi um dia, demorou muito, voltou no outro, e tava demorando e ela disse: "Eu não vou ficar na fila por causa de 30 e poucos reais. Eu preciso, mas eu não vou ficar na fila". Se sentiu humilhada nessa situação. Aí depositaram o dinheiro, mas ela já tinha desistido.

Assim, Cacilda - corroborando a ideia de Duvoux (2009) - afirma que o sentimento de vergonha e a incorporação do estigma não aparecem como aleatórios entre os beneficiários. Quanto mais humildes (para usar a expressão de Cacilda), ou quanto mais resilientes (nos termos de Dubois, 2010), maior é a chance de submissão a processo de humilhação e de aceitação da imputação do estigma. Isto pode ter relação com a falta de um repertório educacional mínimo para a consecução da reação e enfrentamento do estigma. O silenciamento, sobretudo entre os mais humildes, representa, muitas vezes, a aceitação de sua condição, o que podemos observar nas filas de cadastramento para o recebimento do Bolsa Família.

No que se refere a constrangimentos específicos sofridos por essa população, Raquel (professora) avalia que os beneficiários investem o dinheiro de uma forma errônea e, ao fazê-lo, atraem, por consequência, julgamentos morais negativos. Assim, segundo ela:

Já ouvi falar: "Ah, você é um esfomeado...". "Ao invés de dar dinheiro, por que não faz outra coisa?", mas isso é mais para fora da comunidade. Eu, particularmente, não gosto porque eu gosto de programas que incentivam. Só não gosto de como é utilizado. Por isso que eu acho que poderia ter uma fiscalização maior. Porque pode estar sendo utilizado para o vício. 
De acordo com as percepções dos agentes institucionais, o aspecto da humilhação geralmente se relaciona à posição de precariedade do sujeito que, ao precisar solicitar o beneficio, passa a ser classificado como miserável (leia-se "esfomeado"), o que produz um sentimento de vergonha e constrangimento constante. Já para Paula (estagiária de Serviço Social), os beneficiários não se sentem humilhados pelo recebimento do benefício em si, mas, sim, pelo atendimento que recebem principalmente:

[...] no âmbito da coordenação do Bolsa Família. Na recepção, as pessoas que trabalham lá se sentem as donas. Aí, já atende beneficiário, do tipo: "Ah, não tem marido não? Com essa aliança aí no dedo, não tem marido!" Meio que atende com desconfiança. São cargos políticos comissionados, né? Aí, a maioria não tem curso superior e atende como Assistente Social. Tem muito preconceito aqui na porta de entrada, de chegar a chamar até de puta, por aí. Eu, por exemplo, já atendi uma pessoa aqui, que começou a falar comigo e começou a chorar. Aí eu perguntei: O que foi? E ela disse: "Eu perdi minha mãe não tem nem dois meses. Eu queria tentar passar para o meu nome, fazer a troca de dependente, para ver se eu consigo receber, e a gente chega ali na frente e já é maltratado. Eu só vim aqui tentar algum direito pra mim que sou mãe jovem, só tenho 19 anos". E eu perguntei: Sua mãe faleceu de quê? Aí, ela disse: "Vê aí no atestado de óbito". Aí eu olhei o atestado de óbito e estava "insuficiência alimentar", ela morreu porque não comia. Ela disse: "Poxa, a gente chega aqui é maltratado e a primeira coisa que tem é a lei do desacato, desacato ao funcionário público dá cadeia".

Neste contexto urbano brasileiro, percebemos que a marca simbólica parece se consolidar mais entre aqueles classificados como "honestos" e como "aproveitadores". Por isso, para se desviar da categoria desmoralizante de "aproveitadores", as pessoas que buscam o benefício ora afirmam que o recurso é temporário (negando, assim, sua dependência frente ao Serviço de Assistência), ora encarnam a imagem de vítima, para demonstrar que realmente precisam do recurso que lhes será transferido, contrapondo a noção de necessidade com aquele interesse. Até mesmo os não beneficiários assistem a (ou ouvem relatos de) experiências de humilhação. Vilma, por exemplo, conta um caso de uma menina que foi solicitar o benefício do Bolsa Família e, como resultado, sentiu a humilhação. Vejamos o relato:

Um dia, uma menina que mora até por aqui chegou chorando por causa da humilhação. Falou que a menina a tratou tão mal que ela disse que não ia voltar mais lá [...]. Aí eu disse: vai amanhã porque, talvez, é outra que vai te atender... Talvez essa tenha amor no coração. E aí quando ela voltou eles disseram: "Você não precisa receber não, você só tem um filho, tá nova e pode ainda trabalhar". $\mathrm{E}$ aqui, minha filha, tem muita gente que sofre para conseguir o Bolsa, viu?

Mesmo sofrendo claras restrições econômicas em sua vida, Mara optou por não solicitar o benefício, exatamente para evitar possíveis humilhações e preconceitos que poderiam ser exercidos pelos representantes do Estado. "Eu prefiro passar necessidade que pedir. Tenho vergonha, né? Já sou pobre e aí vou ficar me humilhando pros outros, pedindo dinheiro?" Dayane também 
resistiu à busca pelo benefício, tendo em vista que, para ela, a possibilidade de "ser beneficiária" significaria passar por um processo de humilhação moral:

Eu não vou me inscrever no Bolsa Família, porque eu não vou ficar na fila horas com minhas crianças para cadastrar, para talvez eu ganhar e receber esta miséria. Eu não vou me humilhar por migalha não, eu hein! Vou ficar todo mês na loteria, para quê? Para ganhar 44 reais. Para você ver, aqui, minhas colegas sai no sol quente a pé para enfrentar fila para receber 40 reais no mês, para ser maltratada. Eu estou fora desta.

Como histórias de humilhação e constrangimento na coordenação do Bolsa Família são relatadas pelos beneficiários no âmbito da vizinhança, alguns desistem de solicitar o auxílio. Eles evitam a interação face a face, porque seria uma forma de preservar sua fachada (Goffman, 2012: I3-I4), definida como regras comportamentais de respeito próprio, que pressupõem o reconhecimento pelo outro de seu "valor social positivo". Isso acontece quando a pessoa resiste em participar de determinados encontros sociais, nos quais poderia ser alvo de tratamento ofensivo. O que verificamos no conjunto dos beneficiários é que eles desenvolvem estratégias que guiarão seus encontros sociais, preservando ou não (dependendo do contexto) suas fachadas.

Grande parte da dificuldade em aceitar tal benefício parece vir também do baixo valor transferido pelo Programa; recusa que talvez não ocorresse, caso o valor fosse maior para o conjunto da família. O sentimento de vergonha estaria menos relacionado à posição de "fracassado" na vida profissional e mais vinculado ao recebimento de uma renda ínfima. É por isso que, muitas vezes, os beneficiários se desviam do status de assistido, com medo das imputações negativas (tais como: "esfomeados", "acomodados" e "vagabundos") que poderiam ser feitas caso viessem a solicitar o auxílio. A explicação da resistência para o recebimento do benefício não se apresenta de forma similar ao caso francês e particularmente americano, no qual o medo de enquadramento no âmbito da assistência se daria pelo reconhecimento de seu fracasso individual frente ao mercado de trabalho.

Em síntese: mesmo sabendo que as interações estabelecidas entre os atendentes da coordenação e os candidatos (e/ou beneficiários) se caracterizam mais fortemente por julgamentos morais (explícitos ou implícitos), outras formas de interação (menos frequentes) se estabelecem no setor de cadastramento; às vezes, marcadas por um mero preenchimento do cadastro, outras, por indicações, dicas e encaminhamentos aos serviços de Assistência Social. Importante aqui fazermos algumas ressalvas metodológicas. No âmbito das representações, os entrevistados relatam suas experiências com os cadastradores muito mais dentro de um quadro afetivo/moral, mas talvez isto se relacione ao fato de que as pessoas em geral relatem menos experiências burocráticas/legais. Todavia, estas representações de moralidades na interação também se confirmam no âmbito da prática, uma vez que ao fazermos uma 
observação participante de fato vimos emergir com força e recorrência categorias sociais de julgamento.

\section{A PERCEPÇÃO SOBRE OS CRITÉRIOS DE ESCOLHA ESTATAL: POR QUE EU?}

O processo de seleção dos beneficiários passa pelo enquadramento social, (in) formal e moral de um grupo, em uma categoria específica: "pobres". Este tipo de focalização ocorre na "porta de entrada" da área de cadastramento do Bolsa Família. O processo de entrada no Programa desenvolve-se ora de maneira conflituosa, ora de modo resignado por parte daqueles que (por força da condição econômica precária ou pelo interesse) se submetem à identificação estatutária de "pobre". A partir de que noções os beneficiários creem ser selecionados? O que justifica sua inclusão em um programa social? Vejamos alguns exemplos expressos pela fala dos beneficiários.

No que tange ao recebimento do benefício, Naiara (beneficiária) mostra-se surpresa com a notícia e, ao mesmo tempo, amedrontada, acreditando que poderia ter feito algo contra o Governo.

Tinha até esquecido. Aí chegou uma carta do posto e a Agente foi na minha casa, dizendo que eu tinha sido sorteada. E eu disse: mas eu não fiz nada, nada contra o Governo (risos), e ela disse: "Fez sim!" Aí ela foi me lembrando... Aí eu fui na reunião com os beneficiários.

Dois pontos, neste relato, nos parecem interessantes: primeiro, a ideia de que ela teria sido sorteada, ou seja, ao acaso (através da sorte), ela teria sido escolhida pelo Governo; segundo, a sua incompreensão de que tivesse direito a alguma coisa, o que fez com que ela se desviasse dessa crença, apostando, ao contrário, que o Governo iria puni-la por algo e não oferecer-lhe um serviço de assistência.

Os candidatos (e beneficiários) sabem que, ao entrar na situação de interação com os atendentes do guichê, correm o risco de vivenciar uma situação problemática; por isso, utilizam a ordem cerimonial/ritual para garantir as normas de polidez e ordem. Neste jogo, o participante deve dar satisfações do "por que estão ali", para que o atendente avalie a coerência de seu discurso e sua legitimidade para o recebimento de um auxílio. Neste contexto, trocam-se, de forma desigual, justificativas de "merecimento" para o benefício: o candidato usa o critério de necessidade e sofrimento como justificativa para receber o Bolsa Família, podendo o atendente lhe dar ou não crédito de confiança para a concessão do recurso.

Um elemento interessante é a diferenciação entre "quem recebe rápido" e "quem demora a receber", feita através do quesito "sorte" que, ao ser investigado mais a fundo, não se apresenta de modo aleatório; ao contrário, 
ele se relaciona ao capital social adquirido no âmbito do cadastro. Esta é a percepção da beneficiária Adelir que ressalta: "Na verdade, eu acho que é porque algumas pessoas têm mais conhecimento com quem trabalha lá dentro, aí libera mais rápido".

Carla, que também recebe o $\mathrm{BF}$, confirma o argumento de Adelir, salientando que "ter conhecidos" no âmbito da Assistência Social agiliza o recebimento do recurso; destacando, ainda, que várias pessoas gostariam de receber, mas desistem por causa da quantidade de burocracia, do tempo gasto na solicitação e do mau atendimento dos técnicos. "Tem muita gente que desiste por conta deste tratamento dos técnicos". Como o tempo de espera para o recebimento varia em cada caso, pergunto por que ela acredita que existe esta diferença de tempo: "Olha, eu recebi em três meses, mas... tem gente que demora dois anos. Minha vizinha recebeu um ano depois". Segundo ela: "muitas recebem pelo conhecimento. Tenho uma colega que tava demorando para receber o benefício, aí o marido dela conhecia um funcionário lá na coordenação, falou com ele e aí ela recebeu rapidinho, até os atrasados".

Gisele (beneficiária) acredita que as pessoas são escolhidas para receber o Bolsa Família através da renda familiar, via noção "de quem precisa mais, né? Quem tem menos renda. No começo, foi meio... quem não precisava tava recebendo, mas depois pediram carteira de trabalho e cortou várias pessoas".

Por que eu? Esta pergunta foi repassada a Simone (beneficiária) que entende sua inserção no programa tanto pela manipulação do uso (e do sentido) da linguagem, quanto pela produção de uma hexis corporal (Bourdieu, I983) que tenta corresponder às expectativas do Assistente Social. Assim, Simone, através de uma ação reflexiva, aciona um comportamento específico:

Depende da conversa da pessoa, né? (risos). Lá, eles veem se a pessoa precisa,
o que ela vai falar, como vai contar os problema. Tem gente que leva o filho
pequenininho para fazer a inscrição, né? Quem quer receber não vai todo ar-
rumado, né? Se tiver precisando mesmo, você não pode ir todo bonitinho. Não
sei, vai da forma de falar da pessoa. Tem gente que convence a pessoa, tem
gente que não.

Como salienta Goffman (2012: I26), uma pessoa pode usar seu sofrimento de modo consciente para que o outro se envolva em seu jogo emocional. A regra do envolvimento é fundamental para a manutenção da interação. Assim, caso haja desinteresse, ignorância ou insensibilidade, a relação caminhará para outro rumo ou será "quebrada". Tomando ainda como referência a obra desse autor, podemos pensar que os atores jogam com uma imagem desvalorizante ou estigmatizante, através de suas vestimentas e modos de se expressar. A partir daí, acionam um papel social de acordo com seu interesse e com o contexto. Para Goffman (2012), é através do componente cerimonial que se fará uma avaliação da pessoa, a fim de julgar suas qualidades como desejáveis (em nosso trabalho, emergem as noções de "verdadeiro", "dedicado" 
e "bom pobre") ou indesejáveis (através de categorias como: "interesseiro", "aproveitador" e "parasita"). Sob a ótica da verdade, o atendente tende a diminuir as convicções de precariedade do candidato, questionando sua condição e demonstrando uma desconfiança moral sobre suas posturas.

O enquadramento, ou não, no status de pobre se dará sob a incorporação (e aceitação, mesmo que temporária) de sua condição de precariedade e também pela aprovação formal (e burocrática) de seu cadastro como sujeito "merecedor" de direito. Vemos, a partir do material empírico, que as pessoas - em alguma medida - calculam o custo de engajamento para entrar, de fato, em uma interação face a face. Este tipo de repertório acionado apresenta-se como uma estratégia social de manipulação (mesmo se contextual) da "identidade de pobre", como uma ferramenta importante para obter sucesso em sua demanda. ${ }^{9}$

Outra ferramenta que colabora para a aprovação do cadastro e recebimento do benefício aparece no elemento "Deus" (na sorte? Na magia?). Esta percepção é desenvolvida por Deilson (beneficiário, marido de Carla), para justificar por que sua família foi escolhida pelo Programa: "Tudo na vida, minha filha, é feito por Deus. A gente foi escolhido por um motivo: foi a mão divina. Não é todo mundo que tem essa chance. Aqui no bairro, tem vários que tentaram e não conseguiram. É só com a força de Deus mesmo".

Já Sérgio (beneficiário, marido de Jucimar) não sabia dizer, ao certo, que critérios o Governo utiliza para selecionar os candidatos, mas acha que "talvez seja pela ficha [...] assim, no documento. Vamos supor que eu tenho três filhos e outro tem, no caso, seis ou cinco, mas talvez aqueles cinco, a renda deles seja maior que a minha". Como podemos perceber, para Sérgio, a seleção se faria de acordo com a quantidade de filhos proporcionalmente à renda do domicílio, percepção que se enquadra nos critérios usados atualmente pelo Programa. Jucimar, sua esposa, crê ter sido selecionada não por uma avaliação formal estritamente técnica sobre sua condição, mas, sim, pelo que ela denomina de "lábia", ou seja, uma forma de manipulação da linguagem, com objetivos de barganha. Com a finalidade de obter um benefício, deve-se convencer o profissional de sua condição de pobre.

Verificamos que se candidatar ao PBF parece quase uma entrevista de emprego, na medida em que os técnicos avaliam o histórico da pessoa, tendo o candidato expectativas de ser selecionado e fazendo de tudo para corresponder ao "perfil" que acreditam que tais técnicos esperam. No âmbito do cadastramento, a incorporação (mesmo que inconsciente) da hexis corporal do pobre aparece como uma tentativa de utilizar o estigma a seu favor, ou seja, de vitimizar sua condição, para o convencimento de que é de seu direito receber o benefício. Tendo em vista que a transferência de renda no Brasil não é de cunho universal, essa estratégia de vitimização se apresenta como importante, na medida em que a demanda esbarra muitas vezes na escassez de 
recursos públicos. Além da composição desse personagem, observamos a utilização da "lábia" como uma maneira relevante de obter sucesso na demanda, ou seja, torna-se importante, no momento do cadastramento, estar bem preparado oralmente e montar um discurso condizente com as expectativas dos técnicos da "porta de entrada".

Sob a ideia de preservação da fachada (Goffman, 20I2), um conjunto de estratégias é mobilizado pelos indivíduos para a composição de seus repertórios, como, por exemplo, a demonstração de si como "bom sujeito". Isso, no entanto, não significa dizer que se trata de fingimento; ao contrário, fundamenta-se em juízos conscientes. A experiência de sociabilidade faz com que as pessoas aprendam a usar (ou a desusar) suas fachadas, através de um processo contínuo que se realiza durante a interação com os outros indivíduos.

Através de seu estudo sobre o atendimento de demanda do serviço assistencial na França, Dubois (20I0: 4) mostra que os indivíduos aceitam se enquadrar no papel de beneficiário, traduzindo sua condição pessoal em termos de categorias administrativas. Verificamos, assim como Duvoux (2009: 23), que: "há casos em que o beneficiário vai fazer seu discurso a partir do olhar da dominação, mas, neste caso, qual será o dispositivo que ele põe em prática?" Parece que apresentar uma postura de "vítima" ou de "pobre" para conseguir um auxílio assistencial tende a corrigir uma estratégia social.

Edilcéia apresenta uma lógica particular entre os nossos entrevistados, na medida em que argumenta ter sido selecionada porque a política de transferência de renda é um direito seu como cidadã. Ao mesmo tempo, no entanto, utiliza o verbo "dar" para representar a política de concessão de benefício do Bolsa Família, o que denotaria uma situação de dádiva e não de direito:

Eu, como cidadã, voto, né? Creio que foi um meio de estar dando uma ajuda até para estar suprindo o desemprego, mas creio eu que se a gente tivesse uma oportunidade, né? Que atualmente tenho procurado, mas tô indo no médico e ainda não posso, tô tomando um remédio forte, né! Tenho um problema sério na minha coluna, mesmo assim eu procuro, faço uma coisa, faço outra, não fico parada. Mas se tivesse mais emprego, mais oportunidade, acho que não precisava estar dando isso. Eu estava até conversando com minha cunhada, sobre o negócio da fome, que teve uma época muito difícil mesmo, né?

Quando se candidatou ao benefício, Gisele não acreditava que poderia receber tal auxílio. Este ceticismo poderia estar relacionado ao fato de não possuir religião, mas a determinação de uma variável para explicar as percepções da entrevistada nos parece apressada.

Confesso a você que eu não acreditei não, até o dia que o meu cartão chegou, que ele pegou pra mim, porque minhas crianças sempre foram muito doentes. Aí, eu que fui, que estava no meu nome. Ele nunca mexeu não, eu coloquei no meu nome. Desde que ele estava aqui, eu que recebi tudinho. Ah, eu não acreditava, achava que era mais uma promessa. Porque, na verdade, a gente vê tanta coisa, né? Igual ao brasileiro vê. Eu achava que era mais uma piada para enganar o povo. 
Elisabeth também não acreditava que iria receber o Bolsa Família, porém, seu motivo é de outra ordem: acreditava que o fato de os funcionários não a tratarem de forma adequada, faria com que sua demanda não fosse levada a sério. "Eu vi assim... que eles nem olhavam na minha cara, né? Aí desconfiei logo. Eles coloca de qualquer jeito pra não receber. Eles não tão nem aí para você. Você vai lá e eles tratam mal. Eu saí dali e vi: não deu".

Já Edilcéia tinha esperanças em receber o benefício. Esta expectativa provavelmente se relaciona à sua religião (evangélica praticante) que parece impulsioná-la a crer no recebimento do Bolsa Família: "Minha filha, eu sempre acreditei, porque se a gente não tem fé, sobra o quê? Tem que ter fé. Demorou, mas eu recebi. É a mão de Deus". Mesmo dizendo anteriormente que foi por causa de seu direito como cidadã, acredita que Deus deu "uma mãozinha".

Participando de interações com os candidatos ao Bolsa Família, perguntávamos sobre suas expectativas em relação ao recebimento do benefício. Ora emergia de seus relatos o que poderíamos chamar de descrença, ora traziam a esperança como um elemento importante para a satisfação de sua expectativa. A esperança de receber o benefício apresentava-se quando a interação no setor de cadastramento era mais leve, ou seja, quando o atendente possuía uma habilidade social (a simpatia) ao atender o público-alvo, alimentando nos candidatos uma grande expectativa de recebimento. Já a descrença, ou aparecia de modo mais geral (por um descrédito político) ou de modo mais específico, quando a interação era marcada por constrangimentos vinculados a julgamentos morais produzidos pelos atendentes da coordenação.

\section{À GUISA DE CONCLUSÃO}

Identificamos, no setor de cadastramento do Bolsa Família, que os pobres, quando entram em interação com os atendentes da coordenação, constroem um papel social de "candidato", desenvolvendo discursos, comportamentos e linguagens próprias a uma situação de entrevista. Esta entrevista não é uma entrevista qualquer; ela tem como objetivo analisar o perfil do cliente (sofrimento, quantidade de filhos etc.), para julgar se a pessoa será legitimada como "pobre" merecedor de uma bolsa. Desenvolver o papel de "humilde", "necessitado" ou "pobre coitado" faz parte do jogo da interação, no qual, aguçar a identidade de "vítima" é necessário como ritual para a aquisição do benefício. A condição da interação no atendimento baseia-se na troca entre a construção de um discurso condizente com o sofrimento e o interesse de escuta ativa para verificar a veracidade da condição do outro.

Caso o candidato não explicite discursivamente sua condição de pobreza, a interação será quebrada ou se tornará meramente burocrática no preenchimento do cadastro, sem indicações importantes para a legitimação de sua demanda. É através da consciência da interação que o candidato ma- 
nipula (pelo exercício de gestos e comportamentos) um papel social de "pobre", condizente com as expectativas do cadastrador. Por ter esta consciência, seu envolvimento com o outro deve servir como forma de convencimento (demonstração de sofrimento e explanação de dificuldades) de que seus problemas merecem ser solucionados. Em geral, tentam demonstrar que sua condição não deriva de um problema pessoal, mas decorre de um "problema social" (perda de emprego, aumento da família etc.).

No âmbito do cadastro, os entrevistados sempre colocam seus sentimentos sobre as regras da política, o que amortiza a rigidez do enquadramento por categorias formais (renda, escolaridade, estado civil). Por conseguinte, a interação caminha mais para o julgamento moral do que para uma avaliação estritamente econômica. A expressão de sofrimento de alguns beneficiários, no momento do cadastramento (olhar triste, cabeça baixa etc.), gera ora sensibilidade e aprovação, ora desencantamento nos atendentes, levando-os a abandonar a ordem sentimental e restituir a ordem concreta de perguntas e respostas. Não há, em nenhum momento, emergência de fingimento (ou da pretensão de neutralidade) por parte dos atendentes. Vimos, ao contrário, no contexto brasileiro, uma publicização de suas opiniões.

Verificamos que os efeitos do Programa de transferência de renda brasileiro têm naturezas diferentes. Por um lado, a inclusão social: o Programa tem como consequência modalidades de inserção (mesmo que precárias) de famílias na esfera do consumo e de serviços de cunho universal, como saúde e educação, gerando uma percepção de melhora da autoestima e da felicidade das beneficiárias. Por outro, a desqualificação moral: os entrevistados sentem-se (em alguns contextos e não na totalidade de suas trajetórias, como parece ser o caso francês) estigmatizados por serem beneficiários de uma política de transferência de renda.

Por fim, vimos como se desenvolvem as oscilações de apoio (redes de solidariedade, amigos e familiares), de participação (nas condicionalidades do programa e na vida do bairro), de identificação (de caráter moral em torno dos beneficiários) e de rejeição (quando se desenvolve o estigma) atravessadas pelos beneficiários em suas interações cotidianas. Assim, o reconhecimento institucional da demanda ora produz reflexos emocionais positivos, ora processos de estigmatização sobre a população beneficiária. 
Mani Tebet Marins é doutora em Sociologia pelo Programa de Pós-Graduação em Sociologia e Antropologia da Universidade Federal do Rio de Janeiro (PPGSA-UFRJ), professora adjunta de sociologia da Universidade Federal Rural do Rio de Janeiro (UFRRJ) e colaboradora do Programa de Pós-Graduação em Ciências Sociais (PPGCS) da mesma instituição. Suas áreas de interesse são políticas públicas, gênero, raça e desigualdade educacional. Publicou o livro Educação superior e relações raciais (2009), e, entre outros artigos, "Percepções de gênero entre casais beneficiários do Programa Bolsa Família” (20I2). 


\section{NOTAS}

I Ao longo do texto utilizaremos pobre como uma categoria nativa, por esta razão ela virá sem aspas.

2 Em geral, os programas de transferência de renda de combate à pobreza priorizam as mulheres como pessoas que auxiliam a quebra intergeracional da pobreza via função do care.

3 Apesar de este Programa não ter sido extinto formalmente, o Fome Zero vem sendo substituído pelo Plano Brasil Sem Miséria.

4 O Programa Bolsa Escola e o Bolsa Alimentação estavam focados nas famílias pobres com crianças.

5 Também se encontram na página do MDS informações sobre número de famílias beneficiárias nos dois segmentos de renda cobertos pelo programa. Ver <www.mds.gov.br>.

6 O Cadastro Único para Programas Sociais identifica e caracteriza as condições socioeconômicas das famílias de baixa renda (entendidas pelo MDS como aquelas que possuem uma renda igual ou inferior a meio salário mínimo per capita ou renda mensal de até 3 salários mínimos). Ver <http://www.mds.gov.br/falemds/perguntas-frequentes/ bolsa-familia/cadastro-unico/beneficiario/cadunico-inclusao>.

7 Todos os nomes aqui foram alterados.

8 Casa Amarela é o nome mais comum utilizado para se referir à Coordenação do Programa Bolsa Família.

9 Uma boa discussão sobre o status do pobre pode ser vista em Katz (I990).

\section{REFERÊNCIAS BIBLIOGRÁFICAS}

Bourdieu, Pierre. (2012). Sur l'État. Cours au Collège de France (I989-I992). Paris: Seuil.

Bourdieu, Pierre. (2007). A distinção: crítica social do julgamento. São Paulo/Porto Alegre: Edusp/Zouk.

Bourdieu, Pierre. (2003). O poder simbólico. Rio de Janeiro: Bertrand Brasil, 2003.

Bourdieu, Pierre. (1983). Sociologia. São Paulo: Ática. 
Dubois, Vincent. (2010). La vie au guichet. Relation administrative et traitement de la misère. Paris: Économica-Études Politiques.

Duvoux, Nicolas. (2009). L'autonomie des assistés. Sociologie des politiques d'insertion. Paris: PUF.

Goffman, Erving. (20I2). Ritual de interação. Ensaios sobre o comportamento face a face. Petrópolis: Vozes.

Goffman, Erving. (1988). Estigma: notas sobe a manipulação da identidade deteriorada. Rio de Janeiro: Guanabara.

Goffman, Erving. (1987). Manicômios, prisões e conventos. São Paulo: Perspectiva.

Katz, Michael. (1990). The undeserving poor: from the war on poverty to the war on welfare. Nova York: Pantheon.

Lamont, Michèle \& Fournier, Marcel. (1992). Cultivating boundaries and the making of inequality. Chicago: The University of Chicago Press.

Peirano, Mariza. (2006). A teoria vivida e outros ensaios de antropologia. Rio de Janeiro: Zahar.

Steensland, Brian. (2006). Cultural categories and the American Welfare State: the case of guaranteed income policy. American Journal of Sociology, III/5, p. I273-1326.

Strobel, Pierre. (2008). Penser les politiques sociales. Contre les inégalités: le principe de solidarité. La Tour d'Aigues: Éditions de l'Aube. 


\section{REPERTÓRIOS MORAIS E ESTRATÉGIAS INDIVIDUAIS DE BENEFICIÁRIOS E CADASTRADORES DO BOLSA FAMÍLIA}

Resumo

Neste artigo pretendemos analisar as representações sociopolíticas e as práticas cotidianas de atores envolvidos de alguma forma na atuação do Estado, em particular, através de uma política de transferência de renda: o Programa Bolsa Família. Tendo em vista esta finalidade utilizaremos aqui os dados obtidos através de entrevistas e observação participante com funcionários do Estado (em particular os cadastradores do Programa, Assistentes Sociais e Agentes de Saúde) e beneficiários (bem como também candidatos) do Bolsa Família de uma periferia da região metropolitana do Rio de Janeiro. Buscamos compreender como no âmbito desta política dois repertórios antagônicos (racional/legal e emotivo) são aplicados contextualmente pelos cadastradores, Assistentes Sociais e Agentes de Saúde. Os alvos deste programa (os pobres) reagem usando ferramentas morais que justificam seu merecimento e/ou desqualificam os outros, reforçando assim repertórios morais (mérito e honra) e não repertórios cívicos (direitos).

\section{MORAL REPERTOIRES AND INDIVIDUAL STRATEGIES OF BENEFICIARIES AND REGISTRARS OF "BOLSA FAMÍLIA" PROGRAM}

Abstract

The article aims to analyze the socio-political representations and daily practices of actors somewhat involved in state action, particularly through a cash transfer policy: Bolsa Família. With this in sight, it uses data from in-depth interviews and participant observation with civil servants (particularly Bolsa Família's registrars, social workers and health civil servants) and Bolsa Familia beneficiaries (as well as Bolsa Família candidates) on the periphery of Rio de Janeiro's metropolitan area. It seeks to understand how, in the context of this particular social policy, two antagonistic repertoires (rational-legal and emotive) are freely applied by Bolsa Familia registrars and social work assistants. The target population of such program (the poor) also react by using moral tools that justify they are deserving of the benefit and others are not, thus reinforcing moral repertoires (merit and honor) rather than civic ones (rights).

\author{
Palavras-chave \\ Pobreza; \\ Bolsa Família; \\ Relação do Estado \\ com beneficiários; \\ Repertórios moral e legal; \\ Cadastradores do \\ Bolsa Família.
}

